\title{
Revealed Comparative Advantage Analysis for Kuwait India Trade
}

\author{
Anwar Al Shriaan $^{1} \&$ Munir Hassan ${ }^{1}$ \\ ${ }^{1}$ Economics Department, Kuwait University \\ Received: June 18, 2017 \\ doi:10.5539/ass.v13n9p110 \\ Accepted: July 5, 2017 Online Published: August 25, 2017 \\ URL: https://doi.org/10.5539/ass.v13n9p110
}

\begin{abstract}
The main objective of the paper is to analyze Kuwait-India Trade in recent years. The paper is discussed in four sections. In the first section, the profile of Kuwait is given followed by the profile of India. The third section is devoted to a review of Literature on this topic. The fourth and fifth sections deal with Kuwait-India Trade Analysis and Revealed Comparative Advantage estimates respectively.
\end{abstract}

Keywords: Kuwait, India, trade, Comparative Advantage, Absolute Advantage \& Revealed Preference

\section{Section 1. Profile of Kuwait}

In this section, the various aspects of Kuwait are outlined in terms of its economic, political and demographic aspects.

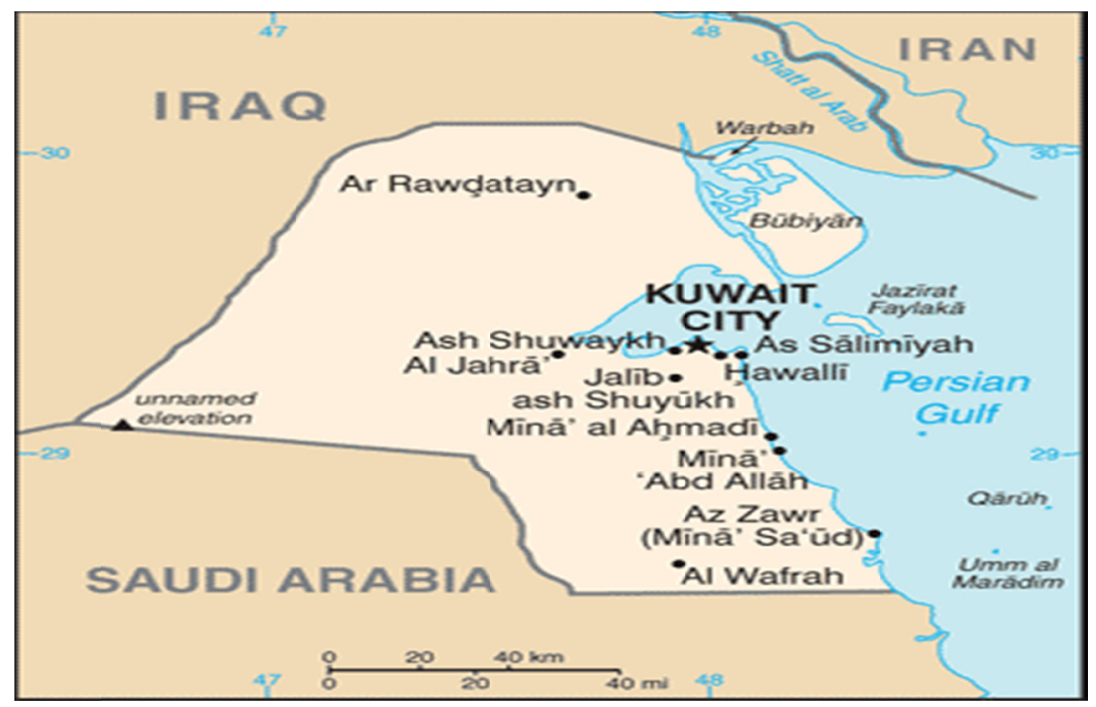

Figure 1

Kuwait is located in the Middle East, bordering the Persian Gulf, between Iraq and Saudi Arabia. It is strategically located at the head of the Persian Gulf. It has a total area of 17,818 sq.km and ranks 158 in the world. It is slightly smaller than New Jersey in United States. It is dry desert with intensely hot summers and short cool winters.

The natural resources are petroleum, fish, shrimp and natural gas. The Population is 2,832,776 and ranks 141 in the world. Only $31.3 \%$ are Kuwaiti and the others are Arab, Asian, African and others. The maximum (52.8\%) are in the age group 25-54 years. In addition, in all categories males exceed females except for the group 65 years and over. The population growth rate is $1.53 \%$ and there are 19.6 births and 2.2 deaths per 1000 population respectively. The Health expenditures are 3\% of GDP. Unemployment is $14.6 \%$ for the ages $15-24$.

Kuwait is a constitutional monarchy and secured its Independence from UK on June 19, 1961. Kuwait's GDP (purchasing power parity) is $\$ 301.1$ billion and ranks 55 in the world. The GDP growth rate is $2.5 \%$ and per capita income is $\$ 71,300$. Agriculture contributes only .4\% to GDP whereas Industry contribution and Services contribution are $59.6 \%$ and $40 \%$ respectively. Fish is the main agricultural product and the major industries are Petroleum, Petrochemicals, cement, shipbuilding and repair, water desalination, food processing and construction materials. The industrial production growth rate is $1.6 \%$, the labor force is 2.546 million, and 
unemployment rate is $3 \%$.

Kuwait has a current account surplus with exports at $\$ 43.84$ billion and imports $\$ 28.32$ billion. The main commodities exported are oil and refined products and fertilizers and its major exporting partners are South Korea (14.8\%), China (12.3\%), Japan (10.6\%), India (9.8\%), USA (7.7\%); Pakistan (6\%) and Singapore (4.4\%). Kuwait imports food, construction materials, vehicles and parts and clothing and its main importing partners are China (13.2\%), USA 9.6\%), Saudi Arabia (7.7 \%), Japan (6.5\%), Germany (5.1\%), France (4.3\%) and India (4.3\%). Inflation rate is $3.3 \%$.

The economy of Kuwait is geographically small but wealthy and relatively open economy with crude oil reserves of about 102 billion barrels (more than $6 \%$ of world reserves).I tis interesting to note that after several years of budget surplus, in 2015, Kuwait faced a deficit .However the government has attempted to reduce the deficit by decreasing spending on subsidies on the local population. By saving annually $10 \%$ of government revenue in the Fund for Future .Generations, the government has cushioned itself against the impact of lower oil prices. Because of uncertain political situation and poor business climate, the Kuwait economy was not able to progress as fast as it could. It was difficult to attract more investment or boost the private sector participation in the economy. (World Fact Book 2017)

\section{Section 2. Profile of India}

In this section the main aspects of the Indian economy and its demographic aspects are given.

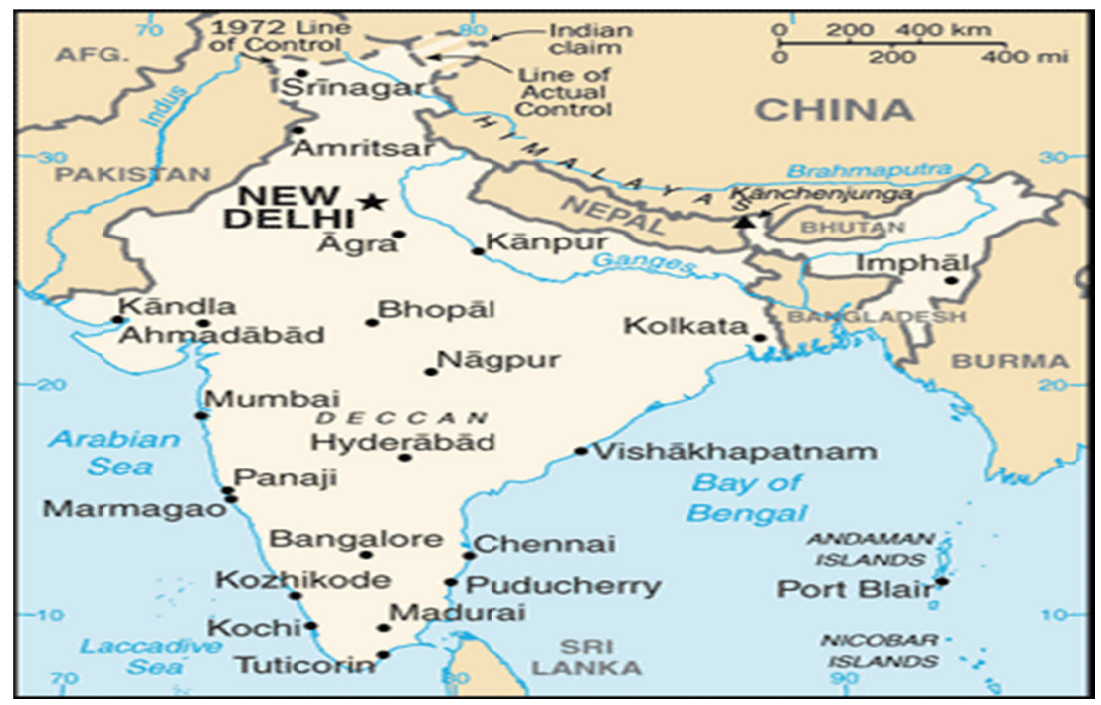

Figure 2

India is emerging as a regional and global power, despite several problems such as significant overpopulation; environmental degradation; extensive poverty and widespread corruption. The launch of economic reforms in 1991 and youthful population are the two driving forces for the rapid economic growth of India.

India is located in Southern Asia bordering the Arabian Sea and the Bay of Bengal between Burma and Pakistan. It has a total area of 3,287,263 ssq.km with land 2,973,193 sq.km and water 314,070 sq.km. It ranks 7 in comparison to the world. It is slightly more than one-third size of the United States. (US)

The natural resources are coal (fourth largest reserves in the world, iron ore, manganese, mica, bauxite, rare earth elements, titanium ore, chromite, natural gas, diamonds, petroleum, limestone and arable land. Agricultural land is $60 \%$; forest $23.1 \%$ and other $16.4 \%$.

The Population of India is $1,266,883,598$ and second in comparison to the world. The maximum population $(40.91 \%)$ is in the age group $25-54$ years with the least $(6.09 \%)$ in the 65 years and over. In all age groups males outnumbered females except for 65 years and over. The Population growth rate is $1.19 \%$ with 19.3 births and 7.3 deaths per 1000 population. The life expectancy at birth is 68.5 years and health expenditures are $4.7 \%$ of GDP. Unfortunately, according to the estimates in 2013, 2,118,100 people are living with HIV/AIDS and ranks $3^{\text {rd }}$ in the world. Education expenditure is $3.8 \%$ of GDP. Youth unemployment (15-24) is $10.7 \%$.

There are 29 States and 7 Union Territories and India got its Independence on 15 August 1947 and became Republic on 26 August 1950.The legal system is common law based on the English model; separate personal law codes apply to Muslims, Christians and Hindus. 
India has a diverse economy with traditional village farming, modern agriculture, handicrafts, a wide range of modern industries and a multitude of services. However, the major source of economic growth is the service sector, which accounts for nearly two thirds of the country's output but employs less than one third of the labor force. India is a major exporter of information technology services, business outsourcing services and software workers. The average growth rate is nearly 7\% per year for the period 1997-2016.Thi is due to the economic liberalization measures such as industrial deregulation, privatization of state owned enterprises and reduce controls on foreign trade and investment. India ranks $4^{\text {th }}$ in GDP (purchasing power parity) which is $\$ 8.721$ trillion and it ranks $7^{\text {th }}$ in GDP real growth rate which is $7.26 \%$.It ranks very low (159) in the world in terms of GDP per capita which is $\$ 6700$.Services account for $45.4 \%$ of GDP followed by Industry $(29.8 \%)$ and agriculture (16.5\%).The main agricultural products are: rice, wheat, oilseed, cotton, just, tea, sugarcane ,onions, potatoes, dairy products ,sheep, goats, poultry, and fish. As for industries the main ones are textiles, chemicals, food processing, steel, transportation equipment, cement mining, petroleum, machinery, software and pharmaceuticals. India ranks 13 in the industrial production growth rate (7.4\%).Labor force is 513.7 million and ranks $2^{\text {nd }}$ in the world with $49 \%$ in agriculture followed by services $(31 \%)$ and industry $(20 \%)$.Unemployment rate is $8.4 \%$ and $29.8 \%$ of population is below poverty line. It has a current account deficit with exports $\$ 271.6$ billion and imports $\$ 402$ billion. The main commodities exported are petroleum products, precious stones, vehicles, machinery, iron and steel, chemicals, pharmaceutical products, cereals and apparel and the exporting partners are USA (15.2\%);UAE (11.4\%) and Hong Kong (4.6\%). The major commodities imported are crude oil, precious stones, machinery, chemicals, fertilizer plastics, iron and steel and the import partners are China (15.7\%), Saudi Arabia (5.4\%), and Switzerland (5.4\%). USA (5.3\%) and UAE (5.2\%).Inflation rate is $5.6 \%$.

According to the World Fact Book, the outlook for India's long-term growth is positive due to young population, healthy savings and investment rates and increasing integration into the global economy. However, it faces several challenges in terms of inefficient power generation and distribution system, ineffective enforcement of intellectual property rights, inadequate transport and agricultural infrastructure etc. (World Fact Book 2017)

\section{Section 3. Review of Literature}

There are very few studies specific to the objectives of this study. However, a few studies that explored India-Kuwait trade are outlined in this section.

Elahi and Rahman (2012) in their paper on India's Trade Potential to Kuwait-Problems and Opportunities present their study on the bilateral trade and economic cooperation between India and Kuwait; and export and import items traded between India and Kuwait. In addition they analyzed the percentage change in export and import of major oil and non-oil items, studied the problems and opportunities faced by India-Kuwait bilateral trade and also suggested measures to overcome the problems and improve trade between India and Kuwait. The main conclusion from their study is that there is wide scope for improving the trade and international relations between these two countries. Their argument is that the concept of South-South Cooperation and a new economic order is a novel one and which is applied to trade should also be extended to other sectors such as transport and communication, industry and agricultural development etc. Both countries would benefit. They end the article with the statement that "As regards to the nature and the extent of Indo-Kuwait trade after economic reforms in India, it has it has achieved new dimensions irrespective of the fact that it constitutes only a small percentage of their respective total exports and imports. Still it is significant that the volume of Indo-Kuwait trade i.e. exports and imports have increased substantially during the last two decades and there exist greater potentialities for it in future."

Azhar (2014) presents a detailed study of the economic cooperation between India and Cooperation in his article. The various aspects examined are bilateral trade inclusive of energy imports, Indian expatriate workers in Kuwait and the inflow of remittances, Kuwait aid and prospective Kuwaiti investments.

RigiLadez and Khan (2014) analyze the bilateral trade between India and GCC (Gulf Cooperation Council) countries for 10 years. Among other bilateral trade relations, they did examine the India- Kuwait trade. Their comment was "Centuries ago the first country which established business with Kuwait was India but as other countries started exporting goods to Kuwait then India lost its leading position. Cultural affinities, geographical proximity, historical trade links and presence of a large number of Indian expatriate in Kuwait have all sustained a long and strong relationship over the years.

Both the countries continued to make the trade relations stronger than before. While Kuwait discovered oil then it started exporting oil and pharmaceutical products to India. The major items that are imported from India to Kuwait are cereals, nuclear reactors, boilers, electrical machinery, meat and edible, articles of Iron or steel. Currently, Kuwait is the second largest oil supplier to India from the GCC countries and meets about $10-12 \%$ of 
India's energy need. The bilateral trade between the two countries was $\$ 727.38$ million in 2004-05 and in 2013-14, it has steady increased t0 \$18218.66million, which is a high growth rate. (Brief on India - Kuwait Trade and Economic Relations, 2013) “

Their main conclusion is that the fast economic growth of India and GCC countries made them mutually interdependence and the bilateral trade between the two regions has increased. Kuwait was India's largest trading partner over the period 2004-2005 to 2013-2014.UAE trade is declining recently and if this continues it is quite likely that Kuwait will be India's largest trading partner.

This review of Literature is a limited and concise one but reveals the significance of India-Kuwait trade. The present research focuses on Direction and Composition of India -Kuwait Trade and attempts to get some Revealed Comparative Advantage Estimates.

\section{Section 4. Analysis of Kuwait-India Trade}

India has been consistently among the top ten trading partners of Kuwait. The relationship between India and Kuwait are traditionally warm, close and friendly. Over 8.2 lakhs of Indians live in Kuwait and they are the largest expatriate community in Kuwait. The table below indicates the extent of bilateral trade between the two countries.

Table 3. India-Kuwait Bilateral Trade FY 2011-12 to 2015-16 in US\$ million

\begin{tabular}{ccccccc}
\hline & $2011-2012$ & $2012-2013$ & $2013-2014$ & $2014-2015$ & $2015-2016$ & $2016-17$ (Apr- Jan) \\
\hline India's Exports to Kuwait & $1,181.41$ & $1,061.08$ & $1,061.14$ & $1,198.91$ & $1,247.25$ & $1,229.28$ \\
India's Imports from Kuwait & $16,439.64$ & $16,588.13$ & $17,153.55$ & $13,381.97$ & $4,962.33$ & $3,491.30$ \\
Total & $17,621.05$ & $17,649.21$ & $18,214.69$ & $14,580.88$ & $6,209.58$ & $4,720.58$ \\
\hline
\end{tabular}

Source: M/o Commerce \& Industry, India

Note: Note: POL imports accounted for US\$ 15,731.38 million in the year 2011-12; US\$ 15,737.46 million in the year 2012-13; US\$ 16,121.81 million in the year 2013-14; US\$ 12,228.71 million in 2014-15; and US\$ 4,052.24 million in 2015-16.

From the above table it is seen India's exports to Kuwait increased consistently where India's imports from Kuwait decreased. The total trade has declined over the years. However, India had a deficit in trade.

Below are two graphs showing the total value of Kuwait and India Merchandise Exports and Imports (2003-2013) and also the Value of Commercial Exports and imports (2003-2013).

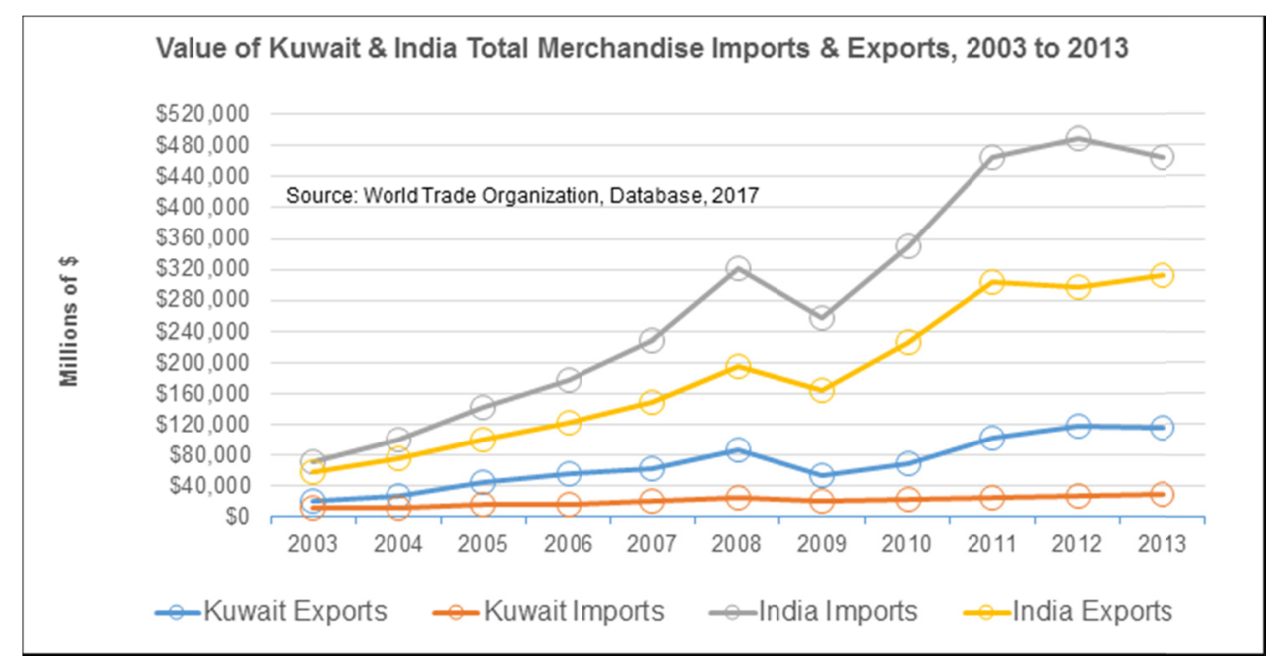

Graph 4. Value of Kuwait \& India Total Merchandise Imports \& Exports, 2003-2013

In the above graph 4, it is observed that India's exports and imports have increased over the years and are consistently higher than Kuwait. For Kuwait, both exports and imports are much lower than Kuwait but have also consistently increased. Kuwait has enjoyed consistently trade surplus over theses years whereas India had a consistently trade deficit.

In the above Graph 5, it is seen that for India commercial exports and imports manifest an increasing trend. For kuwait the exports and imports depict a constant trend. While India experienced consstent deficits from 2005to 
2013, Kuwait had deficit only from 2010.

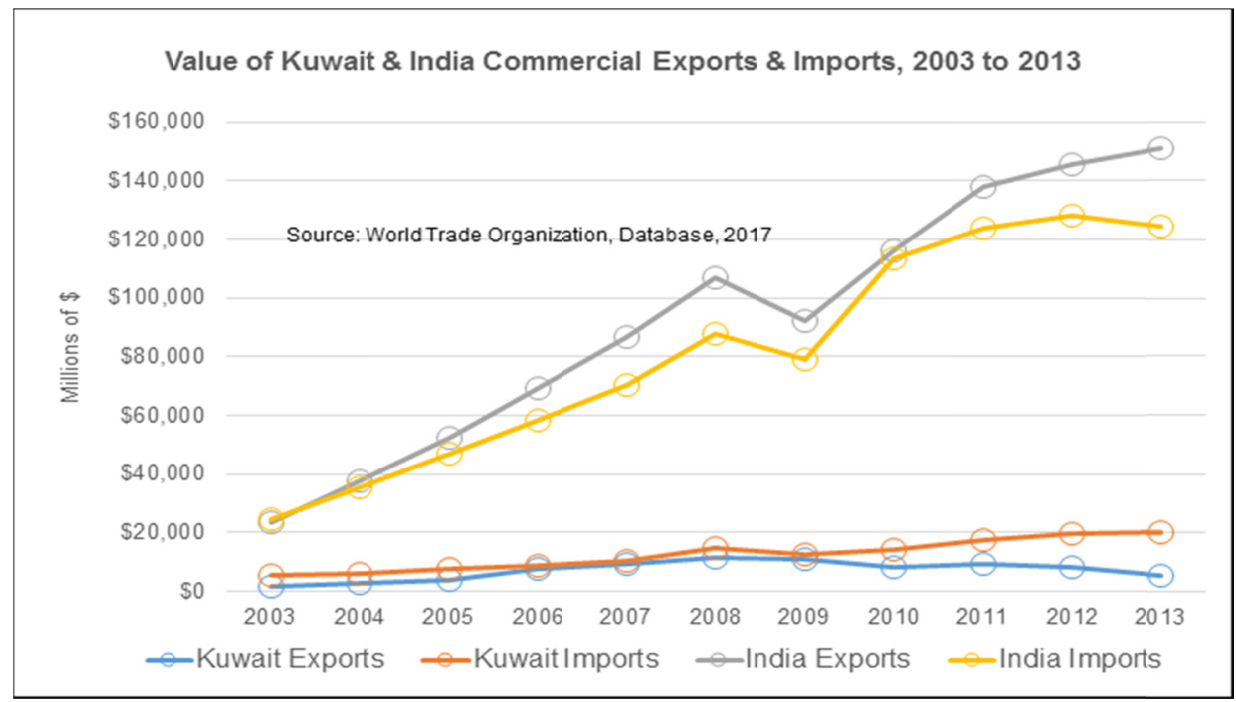

Graph 5. Value of Kuwait \& India Commercial Exports \& Imports, 2003 to 2013

Table 6. Non-Oil Bilateral Trade. India-Kuwait Non-Oil Trade FY 2011-12 to 2015-16

\begin{tabular}{ccccccc}
\hline & $2011-12$ & $2012-13$ & $2013-14$ & $2014-15$ & $2015-16$ & $2016-17$ (Apr- Jan) \\
\hline India's Exports to Kuwait & $1,174.66$ & $1,046.77$ & $1,049.42$ & $1,189.78$ & $1,240.54$ & $1,219.69$ \\
India's Imports from Kuwait & 708.26 & 850.67 & $1,031.74$ & $1,153.26$ & 910.09 & 797.59 \\
Total & $1,882.92$ & $1,897.44$ & $2,081.16$ & $2,343.04$ & $2,150.63$ & 2017.28 \\
\hline
\end{tabular}

Source: Ministry of Commerce \& Industry, India.

As seen from the above Table 6, total non-oil bilateral trade between India and Kuwait decreased by about $-8.21 \%$, i.e., from US\$ 2,343.04 million in 2014-15 to US\$ 2,150.63 million in 2015-16. Meanwhile, India's non-oil exports to Kuwait are showing a positive trend for the past few years. Non-oil export from India to Kuwait increased by about 4\%, i.e., from US\$ 1,189.78 million in 2014-15 to US\$ 1,240.54 million in 2015-16.

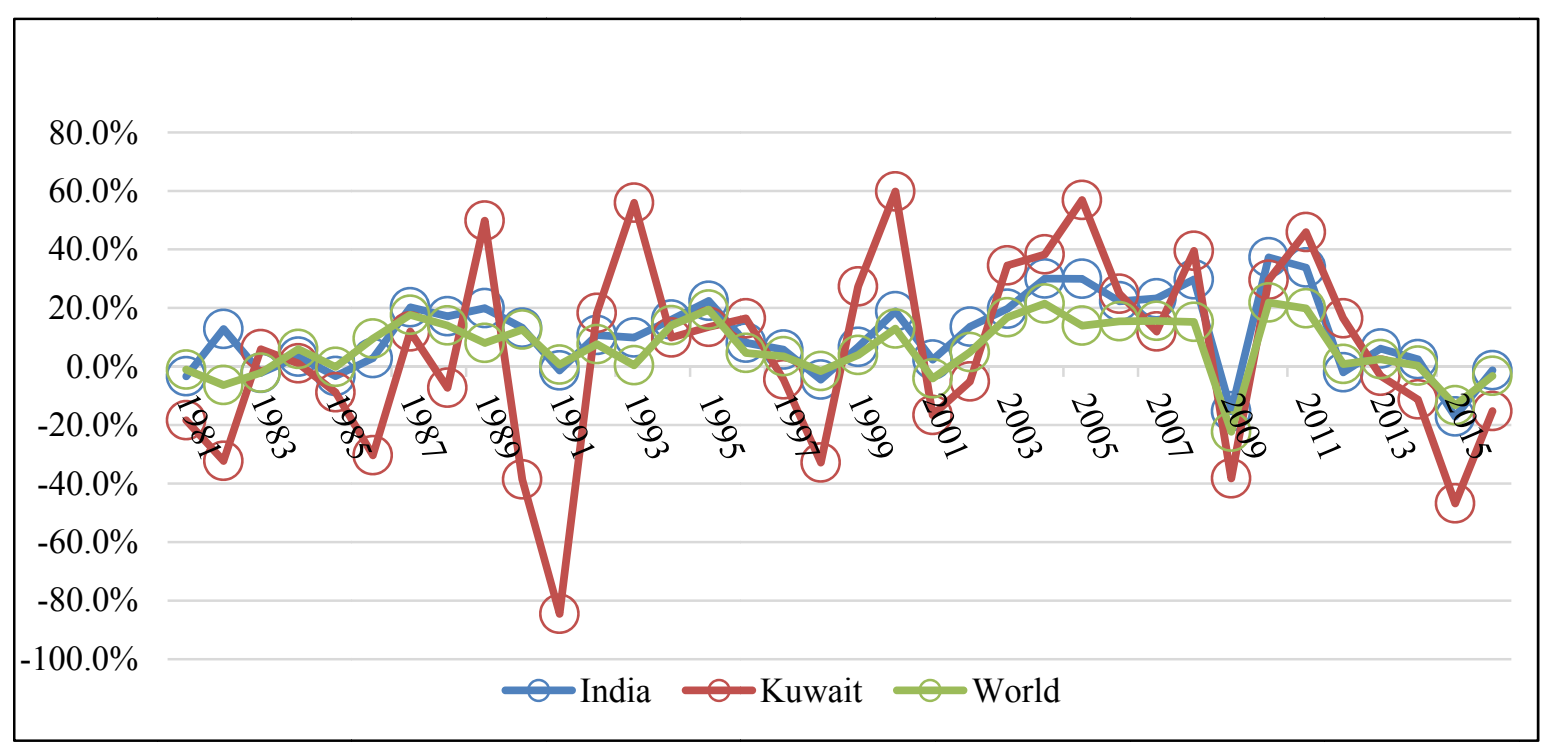

Graph 7. Annual \% Change in Values of Merchandise Exports for India, Kuwait \& the World

From Graph 7 it is seen that there are great fluctauaions in the Annual percentage changes in the Value of Merchandise Trade for Kuwait as compard with India and the World for the period 2003-2013.

In Graph 8, it is seen that World export growth rates are higher for the period 1980-2016 where as both India and Kuwait exhibited lower growth rates but an increasing trend for most of the years. 


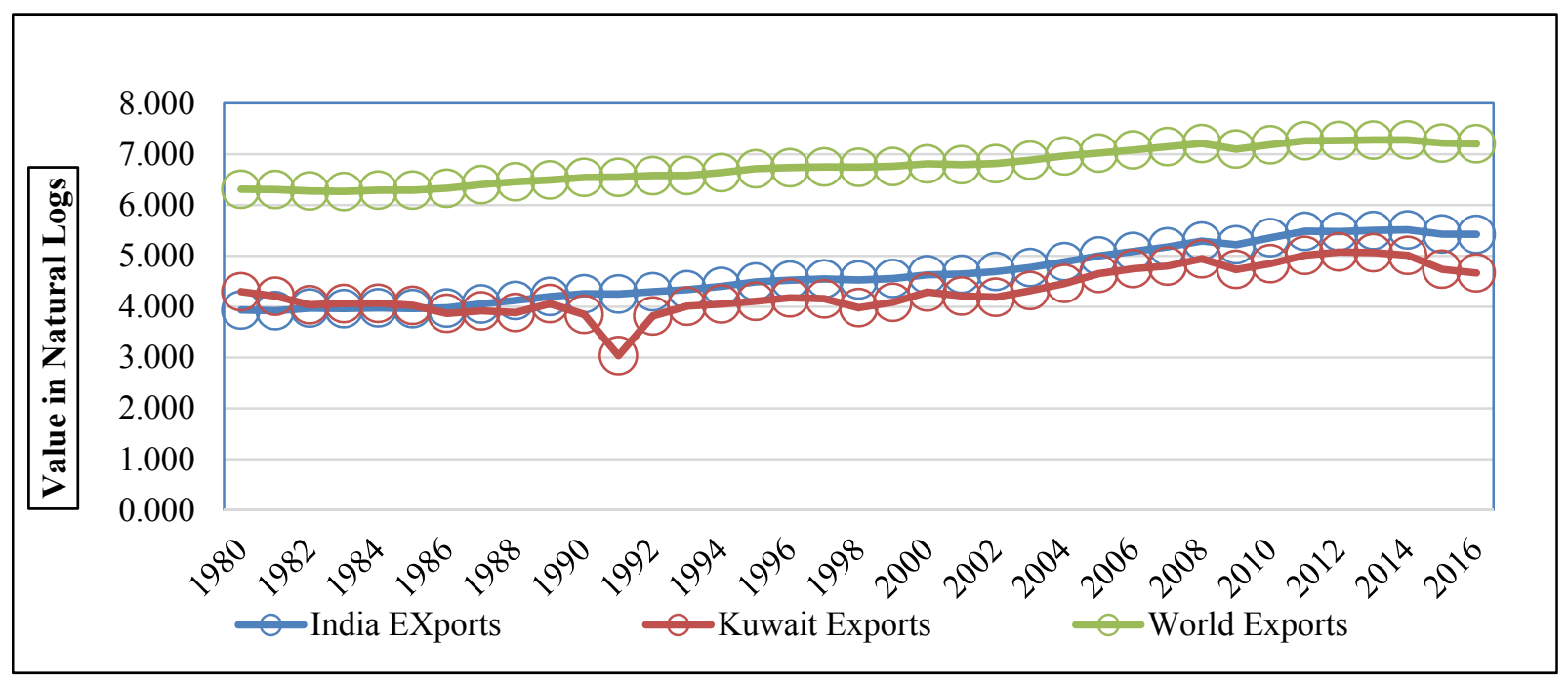

Graph 8. Growth Rate of Total Export Values in Natural Logs for Kuwait, India \& the World In the next section, the estimates for Revealed Comparative Advantage will be presented and analyzed.

\section{Section 5. Revealed Comparative Advantage for Kuwait-India Trade}

Fuels

$\mathrm{RCAij}=(\mathrm{Xij} / \mathrm{Xi}) \quad /(\mathrm{Xaj} / \mathrm{Xa})$

RCA index of Revealed Comparative Advantage

$\mathrm{Xij}=$ exports of product $\mathrm{j}$ from country $\mathrm{i}$

$\mathrm{Xi}=$ total exports from country $\mathrm{i}$

$\mathrm{Xaj}=$ total exports of product $\mathrm{j}$ from the world

$\mathrm{Xa}=$ total exports of the world.

The numerator is the share of good $i$ in the exports of country s, while the denominator is the share of good $i$ in the exports of the world.

The following commodities were considered to estimate the RCA's for Kuwait and India for the period 2006-2015.The results are presented in Tables 5.1 and 5.2

Table 9. Comparative RCA's for Selected Export Sectors of Kuwait and India

\begin{tabular}{|c|c|c|}
\hline & Kuwait & India \\
\hline Year & \multicolumn{2}{|c|}{ Chemicals RCA } \\
\hline 2006 & 0.035 & 1.118 \\
\hline 2007 & 0.036 & 1.026 \\
\hline 2008 & 0.034 & 1.004 \\
\hline 2009 & 0.046 & 0.965 \\
\hline 2010 & 0.055 & 0.931 \\
\hline 2011 & 0.031 & 0.945 \\
\hline 2012 & 0.031 & 1.064 \\
\hline 2013 & 0.053 & 1.086 \\
\hline 2014 & 0.061 & 1.061 \\
\hline 2015 & 0.107 & 1.191 \\
\hline Year & \multicolumn{2}{|c|}{ Ag Products RCA } \\
\hline 2006 & 0.035 & 1.319 \\
\hline 2007 & 0.036 & 1.352 \\
\hline 2008 & 0.034 & 1.316 \\
\hline 2009 & 0.046 & 1.062 \\
\hline 2010 & 0.055 & 1.153 \\
\hline
\end{tabular}




\begin{tabular}{lll}
2011 & 0.031 & 1.261 \\
2012 & 0.031 & 1.572 \\
2013 & 0.053 & 1.557 \\
2014 & 0.061 & 1.456 \\
2015 & 0.107 & 1.389 \\
\hline Year & & \\
\hline 2006 & 0.075 & Automotive Prods RCA \\
2007 & 0.085 & 0.239 \\
2008 & 0.092 & 0.221 \\
2009 & 0.137 & 0.271 \\
2010 & 0.106 & 0.344 \\
2011 & 0.099 & 0.394 \\
2012 & 0.099 & 0.309 \\
2013 & 0.085 & 0.392 \\
2014 & 0.108 & 0.372 \\
2015 & 0.171 & 0.404 \\
\hline
\end{tabular}

From Table 9, the RCA's yielded higher values for India than Kuwait for the chemicals, Ag. Products and Automotive products. The RCA's for Kuwait have been increasing over the years for these three products. For India, the RCA's are much lower for automotive products.

Table 10. Comparative RCA's for selected Export Sectors of Kuwait and India

\begin{tabular}{|c|c|c|}
\hline & Kuwait & India \\
\hline Year & \multicolumn{2}{|c|}{ Fuels/Mining RCA } \\
\hline 2006 & 5.035 & 1.206 \\
\hline 2007 & 5.089 & 1.251 \\
\hline 2008 & 4.401 & 1.062 \\
\hline 2009 & 4.899 & 1.200 \\
\hline 2010 & 4.535 & 1.237 \\
\hline 2011 & 4.316 & 1.028 \\
\hline 2012 & 4.282 & 1.064 \\
\hline 2013 & 4.454 & 1.134 \\
\hline 2014 & 4.776 & 1.190 \\
\hline 2015 & 6.409 & 1.104 \\
\hline Year & \multicolumn{2}{|c|}{ Machinery \& Transport RCA } \\
\hline 2006 & 0.034 & 0.291 \\
\hline 2007 & 0.047 & 0.300 \\
\hline 2008 & 0.055 & 0.370 \\
\hline 2009 & 0.080 & 0.469 \\
\hline 2010 & 0.058 & 0.406 \\
\hline 2011 & 0.057 & 0.424 \\
\hline 2012 & 0.057 & 0.415 \\
\hline 2013 & 0.033 & 0.408 \\
\hline 2014 & 0.043 & 0.445 \\
\hline 2015 & 0.073 & 0.440 \\
\hline Year & \multicolumn{2}{|c|}{ Textiles RCA } \\
\hline 2006 & 0.010 & 3.846 \\
\hline 2007 & 0.011 & 3.601 \\
\hline 2008 & 0.010 & 3.322 \\
\hline 2009 & 0.012 & 3.181 \\
\hline 2010 & 0.005 & 3.327 \\
\hline 2011 & 0.010 & 3.066 \\
\hline
\end{tabular}




$\begin{array}{lll}2012 & 0.010 & 3.278 \\ 2013 & 0.009 & 3.371 \\ 2014 & 0.011 & 3.364 \\ 2015 & 0.021 & 3.567\end{array}$

As seen from Table 10, the RCA's yielded higher values for India than Kuwait for the chemicals, Ag. Products and Automotive products. The RCA's for Kuwait have been increasing over the years for these three products. For India, the RCA's are much lower for automotive products.

\section{Conclusions}

The main theme of the paper is to analyze Kuwait -India Trade in recent years. In the first and second sections the profiles of Kuwait and India are given respectively. From this section it is observed that the Economy of Kuwait is geographically small but wealthy and relatively open economy with crude oil reserves of about 102 billion barrels (more than $6 \%$ of world reserves). It is interesting to note that after several years of budget surplus, in 2015, Kuwait faced a deficit. However the government has attempted to reduce the deficit by decreasing spending on subsidies on the local population. By saving annually $10 \%$ of government revenue in the Fund for Future Generations, the government has cushioned itself against the impact of lower oil prices. Because of uncertain political situation and poor business climate, the Kuwait economy was not able to progress as fast as it could. It was difficult to attract more investment or boost the private sector participation in the economy. (World Fact Book 2017)

According to the World Fact Book, the outlook for India's long-term growth is positive due to young population, healthy savings and investment rates and increasing integration into the global economy. However, it faces several challenges in terms of inefficient power generation and distribution system, ineffective enforcement of intellectual property rights, inadequate transport and agricultural infrastructure etc. (World Fact book 2017)

The table below gives the comparisons.

Table 11. Comparisons of Kuwait and India

\begin{tabular}{ccc}
\hline & Kuwait & India \\
\hline Population & $2,832,776$ & $1,266,833.598$ \\
Age group (25-54 years) & $52.8 \%$ & $40.91 \%$ \\
GDP (PPP) & $\$ 301.1$ billion & $\$ 8.721$ trillion \\
Agriculture & $.4 \%$ & $16.5 \%$ \\
Industry & $59.6 \%$ & $29.8 \%$ \\
Services & $40 \%$ & $45.4 \%(2016$ est $)$ \\
Exports & $\$ 43.8$ billion & $\$ 271.6$ billion \\
Imports & $\$ 28.32$ billion & $\$ 402$ billion \\
Trade & Surplus & Deficit \\
Inflation & $3.3 \%$ & $5.6 \%$ \\
Unemployment & $3 \%$ & $8.4 \%$ \\
Exports to India/Kuwait & $9.8 \%$ & \\
Imports from India/Kuwait & $4.3 \%$ & \\
\hline
\end{tabular}

From the above table 11 it is seen that India is a major importing and exporting partner for Kuwait and hence it was decided to examine the trade between these two countries although there is great disparity in the economy size.

In the third section the Review of literature is given. Although the review is short and concise it is observed that, none of the studies has analyzed Kuwait-India trade in terms of Revealed Comparative Advantage Analysis and so the study was undertaken with this objective in mind.

In the fourth section the Analysis of Kuwait-India Trade is given. The following conclusions are given from the various Tables and Graphs presented in Section 4. 
From Table 3 it is seen India's exports to Kuwait increased consistently where India's imports from Kuwait decreased. The total trade has declined over the years. However, India had a deficit in trade.

Graph 4 reveals that that India's exports and imports have increased over the years and are consistently higher than Kuwait. For Kuwait, both exports and imports are much lower than Kuwait but have also consistently increased. Kuwait has enjoyed consistently trade surplus over theses years whereas India had a consistently trade deficit. From Graph 5 it is seen that for India commercial exports and imports manifest an increasing trend. For kuwait the exports and imports depict a constant trend. While India experienced consstent deficits from 2005to 2013, Kuwait had deficit only from 2010.

From Table 6 Total non-oil bilateral trade between India and Kuwait decreased by about $-8.21 \%$, i.e., from US\$ 2,343.04 million in 2014-15 to US\$ 2,150.63 million in 2015-16. Meanwhile, India's non-oil exports to Kuwait are showing a positive trend for the past few years. Non-oil export from India to Kuwait increased by about 4\%, i.e., from US\$ $1,189.78$ million in 2014-15 to US\$ 1,240.54 million in 2015-16.

From Graph 7 it is seen that there are great fluctauaions in the annual percentage changes in the Value of Merchandise Trade for Kuwait as compard with India and the World for the period 2003-2013. In Graph 8, it is seen that World export growth rates are higher for the period 1980-2016 where as both India and Kuwait exhibited lower growth rates but an increasing trend for most of the years.

In Section 5, the results from the Revealed Comparative Advantage (RCA) Analysis are presented. The methodology is explained in detail in this section. Two tables are given in this section and the commodities for which RCA's are estimated are Chemicals, Ag Products, Automotive Products, Fuels/Mining, Machinery \& Transport and Textiles and the period selected is 2006-2015. The choice of the commodities and the period are dictated by availability of data.

From Table 9 it is seen The RCA's yielded higher values for India than Kuwait for the chemicals, Ag. Products and Automotive products. The RCA's for Kuwait have been increasing over the years for these three products. For India, the RCA's are much lower for automotive products.

From Table 10, the RCA's yielded higher values for India than Kuwait for the chemicals, Ag. Products and Automotive products. The RCA's for Kuwait have been increasing over the years for these three products. For India, the RCA's are much lower for automotive products.

The main overall conclusion from the Analysis is that there is great scope for future trade between Kuwait and India and it would be mutually beneficial due to the proximity of the countries geographically and to a certain extent culturally too.

\section{References}

Azhar, M. (2014). Economic Cooperation between India and Kuwait: Performance and Prospects. Middle Eastern Studies, 50(1), 100-113.

Balassa, B. (1965). Trade Liberalization and 'Revealed' Comparative Advantage. Manchester School 33, 123.

Balassa, Bela (1967). Revealed Comparative Advantage Revisited: Analysis of Relative Export Shares of the Industrial Countries, 1953-1971. Manchester School, 45, 327.44

Central Intelligence Agency (CIA). World Fact book (2016). Retrieved from https://www.cia.gov/library/publications/resources/the-world-factbook/

Elahi, Y., \& Rahman, A. (2012). India's Trade Potential to Kuwait - Problems and Opportunities. International Journal of Computing and Corporate Research, 2(6).

M/o Commerce \& Industry, India (2016).

Revealed Comparative Advantage Revisited: Analysis of Relative Export Shares of the Industrial Countries, 1953-1971 (1967). Manchester School, 45, 327.44

RigiLadez, Saeed, Khan, Mohd, (December 2014). Trade relations between India and Gulf cooperation council countries - An empirical Study. International Research Journal of Business and Management, 7, 13. 21.

\section{Copyrights}

Copyright for this article is retained by the author(s), with first publication rights granted to the journal.

This is an open-access article distributed under the terms and conditions of the Creative Commons Attribution license (http://creativecommons.org/licenses/by/4.0/). 